\title{
Zhu Wen, I Love Dollars and other Stories of China, trans. With a foreword by Julia Lovell, New York, Columbia University Press, 2007, 228 pp
}

\section{Sebastian Veg}

\section{OpenEdition}

\section{Journals}

Édition électronique

URL : http://journals.openedition.org/chinaperspectives/1503

DOI : $10.4000 /$ chinaperspectives. 1503

ISSN : 1996-4617

Éditeur

Centre d'étude français sur la Chine contemporaine

Édition imprimée

Date de publication : 15 janvier 2007

ISSN : 2070-3449

Référence électronique

Sebastian Veg, «Zhu Wen, I Love Dollars and other Stories of China, trans. With a foreword by Julia Lovell, New York, Columbia University Press, 2007, 228 pp », China Perspectives [En ligne], 2007/1 | 2007, mis en ligne le 08 avril 2008, consulté le 22 septembre 2020. URL : http://

journals.openedition.org/chinaperspectives/1503; DOI : https://doi.org/10.4000/chinaperspectives. 1503

Ce document a été généré automatiquement le 22 septembre 2020.

(c) All rights reserved 


\section{Zhu Wen, I Love Dollars and other Stories of China, trans. With a foreword by Julia Lovell, New York, Columbia University Press, 2007, $228 \mathrm{pp}$}

Sebastian Veg

Zhu Wen, born in Quanzhou (Fujian Province) in 1967, is a writer of the 1990s whose work is now available for the first time in a Western language, thanks to Julia Lovell's translation. After studying mechanics, Zhu Wen obtained a job in a thermal power plant, which he left in 1994 to take up full-time writing. A scandalous poet and novelist in the cynical vein of Wang shuo during the upheavals of the 1990s, he became known to a wider international audience after 2001, when he turned to cinema. He had already authored two scenarios (for Zhang Yuan's Seventeen Years, and Clouds and Rain in Wushan by Zhang Ming), when he directed Haixian (Seafood) in 2001, which won prizes at the Venice and Nantes film festivals, then South of the Clouds in 2004, which received a special prize at the Berlin Festival. While he has said time and again that he has done with literature, a selection of his short stories has just recently been reissued under the title Dama de yuqi (Dama's tone).

As Julia Lovell points out in her detailed introduction, the six short stories by Zhu Wen brought together here constitute first and foremost a critique of the China of economic liberalisation where "the social contract-if it ever existed-is now in tatters" (p. xv). The second story "A Hospital Night" illustrates the tensions stemming from the traditional family obligations that reappear in the context of non-existent public services, undermined by the economic reforms. Indeed, hospitals in China for the most part provide only medical care (for a fee), while the costs of food and non-medical facilities for the patients are borne by members of the family, who must take turns at the bedside of the relative. In this story, in order not to be exposed to the criticisms of 
her family over her divorce, the protagonist's female friend asks him to play the role of the son-in-law at the bedside of her father, who has had a kidney stone operation at the Workers' Hospital. The night vigil then takes on the aura of an epic struggle between old Li, who has decided to do everything to make the young man's life difficult, and the protagonist who is resigned to seeing that he eats, drinks and urinates (without forgetting to make the most of it by ogling the nurses in the corridors). The hospital room, with its five convalescent patients, also presents a picture of Chinese social contrasts, placing an affluent hypochondriac alongside a retired worker with an inoperable stomach cancer. Each of the patients takes sides in the struggle between $\mathrm{Li}$ and his "son-in-law", and the latter's revenge, when he deprives Li of water, asking him to apologise first, cannot fail to delight the reader, however cruel it may be.

3 Beyond its satirical vein (which is displayed in particular around the introduction of a "pee bottle" under old Li's bed cover), the author exposes the hypocrisy of a family system in which each person makes a virtue of seemingly honouring filial piety at the same time as doing their best to avoid its least pleasant aspects. From this point of view, the text's indulgence on the scatological is nothing new, recalling May Fourth satires of the Twenty-four images of filial piety, a manual that in one instance extols a son who tastes his father's excrement in order to determine the illness he is suffering from $^{1}$.The failure of the local authorities to take care of the sick or the aged makes people dependent on the constraints of traditional solidarity, which is at the same time being eroded by economic liberalism. In addition, beyond any system, it is also the war of all against all that is highlighted by this fight to the bitter end between the unworthy old man and his young warden who, when he finally gives him something to drink, has all the water spat back in his face by way of thanks.

The same subject of clan solidarity in the face of illness can be found in another form in "Wheels", in which the narrator, a power-station worker, is the victim of extortion by a local racketeer who runs a roast goose restaurant, after grazing his grandfather when passing him on a bike in the street. The gangster forces him to pay firstly for a full medical exam for his grandfather, including blood and radiological tests, amounting to 781 yuan then, when the doctor diagnoses stomach cancer, asks him for a full settlement payment of 3,000 yuan, on account of the absence of any social security and his grandfather's state of material destitution. While the family also stands in for the state, which is failing in its duty, it does so in the manner of the mafia, with the restaurant owner terrorising the whole neighbourhood. The exasperated narrator ends up defying the death threats and takes vengeance by smashing up his enemy's restaurant-and with success, it would seem, since we read at the start of the story, written in the first person, that it all took place "six years ago" (p. 252), and that therefore the narrator survived his rebellion intact.

5 The fact that the protagonist of "Wheels" is a worker in a power plant means that Zhu Wen is also addressing the decline of state industries, which is at the heart of "Ah, Xiao Xie" arguably the most enigmatic of the collection's stories. The electrical plant where the narrator works is a prototype purchased from the Soviet Union before 1991 and so has never been finished. In this situation in which the factory is in a bad way, different strategies emerge, the most resourceful workers selling themselves to Hong Kong or American companies. The computer programmer Xiao Xie on the other hand is constantly in negotiation, anticipating, then rejecting the management's offer of a termination package, but at the last minute hesitates to give up his medical insurance 
for a better-paying job. Xia Yuqing, his first room-mate (in the bachelor dorms, another symbol of the socialist world), for his part opts for a mediocre but secure career in the work unit, wondering whether he might not take advantage of the boss's alleged sexual preference for men in order to climb the ladder more quickly. He subsequently seems to transfer his plans for seduction to other colleagues, among them Xiao Xie, who all end up falling out of a window. The very name of Xiao Xie, which, thanks to a play on words in Chinese, is a homophone for sexual impotence, finally becomes the stock expression in the factory for a "loser", and the story thus brings out both the absurdity of life in the state-owned enterprises undermined from within, and the blossoming in this context of all sorts of desires felt to be shameful by the characters.

6 In "A Boat Crossing", which takes up the stifling atmosphere and the geographic context of the Three Gorges used in the scenario of Clouds and Rain in Wushan, the narrator leaves Cape Steadfast, where he is accompanied by two sinister teachers from the local Party school, Chen and Qi, who are connected to him by obscure debts, and embarks on a boat going up the Yangtze River. On it, he shares a filthy cabin with three gangsters who hint that they are carrying a corpse. They are joined by a woman whose face is familiar to the protagonist, and who tries to sell him a 17-year-old girl for 4,000 yuan. The bag of oranges in the shape of goose eggs, a local specialty given to the narrator by Chen and Qi as a parting gift, and subsequently looted by everybody, is the symbol of the multiple links of obligation that dog the main character. But when he abandons the bag and his cabin to the woman to seek refuge in a higher class (against payment of course), his new cabin companion, a electrical batteries sales rep named Lin Yicheng and an overweight insomniac, again prevents him from sleeping by an endless monologue on his marital problems (his boss is having an affair with his wife), and finally feeds him rice soup sweetened with fruit. This time, it is the narrator who attempts to limit the relationship within the borders of a monetary transaction, by paying his oversized neighbour 5 yuan for his portion of rice soup, in order to sever the mutual bonds of duty which oblige him to listen, and finally get some sleep. In spite of that, his presence alone earns him the gratitude of Lin who follows him onto land and, through a remarkable set of circumstances, forces him back on board the boat with him to continue the trip. Beyond the undeniable role of money, and the portrait gallery of original characters (typical of the Far West that the China of the Three Gorges is today) who are connected to the narrator through money, it is more broadly the omnipresence of self-interested relations that gives this short story both its diffuse atmosphere of threat and its strain of social critique.

7 Lastly, problematic family obligations are again at the core of the first story in the collection, "I love dollars", in which a father comes to town to pay a visit to his two sons, one a writer, whom he disturbs in full flight in bed, the other a rock musician (named $\mathrm{Zhu} \mathrm{Wu}$, which subtly suggests that the narrator is called Zhu Wen). The afternoon that the latter spends in town with his father illustrates the idea of leisure that the son feels bound to get him to enjoy, having his hair dyed black by a female hairdresser from Wenzhou and having him consume all sorts of useless products ranging from a cup of Coca Cola to fake Miao necklaces, before ending up at the movies with two young girls whose presence is designed to liven up the rest of the evening's entertainment. In actual fact, the father steals away, leaving the cinema, and giving the necklace to one of the girls before sending her packing. In the evening, during a new attempt, they end up lacking the money to pay the two girls they bring home, and when, to crown it all, the protagonist asks the woman he regularly sleeps with to 
sacrifice herself for his father, he only gets a slap in the face for an answer. All the stories thus set up a parallel between the world of the family and that of the danwei, one being just as oppressive and dreary as the other. Zhu Wen thus aims to show the extent to which social organisations based on a clan structure remain burdensome under the mouldy crust of socialist society.

Julia Lovell puts forward the view that the pact that enabled the success of the postTiananmen generation rests upon the possibility of criticising everything barring politics. However, Zhu Wen has expressed himself somewhat differently on the matter. After emphasising that, for him, the main quality of a writer is "to see through things" at first glance, he adds that, when he first took up the pen, he was hoping to "change things", a hope that was dashed when he realised that it was rather writers who adapted to the times ${ }^{2}$. His fiction of the 1990s therefore appears to him above all as the expression of a personal revolt, faithfulness to which made him decide to give up literature. Julia Lovell tends to reduce this revolt to a moral critique of post-communist society. For her, "Zhu Wen tells China exactly as he finds it: seedy, selfish, amoral, corrupt" (p. xii), detaching himself from moralising only through the lightness of his narration. Jonathan Mirsky goes even further in a recent book review, denouncing a work that, while appearing to be scandalous, is in actual fact superficial and "devoid of any plot" ${ }^{3}$ written only for shock value. These assessments seem somewhat one-sided.

In our view, by using a writer protagonist, the story "I love dollars" casts a different light on Zhu's conception of writing. Priding himself on the fact that this story, which made him famous, was written in three days and nights, Zhu Wen links writing to the metaphor of a biological need that he is fond of. The difference between writing poems and narrative is thus the same as that between "making love and giving birth"4 or again, the censorship of the office of cinema tries to "ban someone from pissing just because they once aimed to the side of the basin" 5 The narrator of the story also makes this connection, stating that he turned to writing as a palliative ("a sort of intellectual laxative", p. 4) in order to entertain himself when he could no longer satisfy his daily need for copulation. Zhu Wen the writer, too, promotes the consumable nature of his production. He writes because he feels compelled to say new things, in the enthusiasm of youth, rejecting routine, and prefers to turn to cinema rather than repeat himself. This writing is indeed related to a particular generation; in the story, the girl-friend of the narrator's brother admires what he writes, unlike his father, who solemnly asks him to give up writing, thereby provoking an unexpected attack of nausea right there in the restaurant (p. 32). While his father, reading his manuscripts through the night, lectures him: "A writer ought to offer people something positive, something to look up to, ideals, aspirations, democracy, freedom, stuff like that", the narrator merely replies, "Dad, I'm telling you, all that stuff, it's there in sex" (p. 34). The change of generation here takes the form of a clash between two conceptions of literature, the one inherited from May Fourth (actually not far removed from a traditional view of the role of the writer), which persisted until the dissidents of the 1980s and the 1989 student movement, in which literature served to enlighten the reader; the other, a form of writing that turns its back on any attempt to put the writer above his or her readers, in the position of guide. There is, it seems to us, some hypocrisy on the part of critics (Western and Chinese ${ }^{6}$ ) who right up until the 1980s were denouncing the submission of literature, including literature that was critical of power, to an ideological programme, and now vocally lament that this connection has been severed. 

is trying to develop a critique of consumer society that is not merely moralising-a stance that, to his credit, he never adopts. While stressing the relative freedom, in particular in the life of individuals, that economic liberalisation has allowed ${ }^{7}$ he shows how individuals are crushed under an array of power structures, of which the socialist work unit continues to be a part, but which also encompass the traditional structure of the family, and the economic violence of unbridled capitalism. The humour and irony of the narrators give flesh to this diffuse resistance which, even if it contains cynicism in part, is not simply about posturing. In short, the timely publication of this collection, with the help of an excellent translation, enables us to hear the voice of an innovative writer and filmmaker, who has contributed to shaping the present-day Chinese literary world.

\section{NOTES}

1. Cf. for example: Lu Xun "How to carry out our role as fathers today", Selected Works, Beijing, Foreign Language Press

2. "Zhu Wen fangtan: shenghuo de dongli jiu shi xugou" (Interview with Zhu Wen: "Fiction is the driving force of life"), Tamen, $\mathrm{n}^{\circ} 14$ (2007), http://www.tamen.net/ publish/14-4.htm . All websites were accessed on 1 May 2007

3. J. Mirsky, "A Negative Version of Today's China”, Far-Eastern Economic Review, vol. 170, n² 2 (March 2007), pp. 73-74.,

4. Li Hongqi, "Renmin daodi xubuxuyao Zhu Wen?" ("In the end, do the people need Zhu Wen?"), http://culture.netbig.com/topic/935/20010130/97453.htm

5. "Zhu Wen fangtan: wode dianying bu neng meiyou shiyi" ("Interview with Zhu Wen: my films cannot not contain poetry"), in Ouyang Jianghe (ed.), Zhongguo duli dianying (Independent Chinese Cinema), Hong Kong, Oxford University Press, 2007, pp. 141-155.

6. Cf. for example, the recent controversy surrounding the remarks by Wolfgang Kubin, a good account of which can be found on the website EastSouthWestNorth: http:// www.zonaeuropa.com/culture/c20061214_1.htm

7. In this vein, the final story in the collection, "Pounds, ounces and meat", which we have not discussed owing to its brevity, portrays a narrator living with a woman to whom he is not married and whom he describes as his "current girlfriend". 